\title{
特発性三叉神経痛の保存的治療とその問題点
}

\author{
山本哲也·米田和典·植田栄作 \\ 加 藤 斎・尾崎登喜雄
}

\section{Conservative therapy and its problems in idiopathic trigeminal neuralgia}

\author{
Tetsuya Yamamoto $\cdot$ Kazunori Yoneda $\cdot$ Eisaku Ueta \\ Itsuki Kato $\cdot$ Tokio OsaKI
}

\begin{abstract}
Sixty patients with idiopathic trigeminal neuralgia (ITN) were clinically investigated and the following results were obtained. 1) The 3rd branch of the trigeminal nerve was involved in 33 patients ( $55 \%)$, the 2 nd branch in 23 patients $(38.3 \%)$, and $1 \mathrm{st}+2 \mathrm{nd}$ or $2 \mathrm{nd}+3$ rd branches in 4 patients (6.7\%). 2 ) Most patients underwent nerve block of the infraorbital and mental nerves and received carbamazepine. After frequent nerve block with $0.5 \%$ bupivacaine hydrochloride, analgesia of the nerve-inervated tissues persisted for a long period, similar to that during nerve block with 100\% alcohol. 3 ) Within 6 months after successful treatment, pain recurred in 25 patients $(41.7 \%)$, and re-recurrence occurred in 14 of these 25 patients $(56.0 \%)$. In addition, ITN recurred three times in 9 of the 14 patients (61.3\%). 4 ) In patients with recurrence, the face and oral cavity were broadly involved and, pain attacks were more frequent than those in patients without recurrence. These results indicate that blockade of the infraorbital and mental nerves by local anesthetics is useful in the management of ITN, that severe ITN tends to recur, and that ITN sometimes worsens during the course of recurrence, which complicates the treatment of ITN.
\end{abstract}

Key words: idiopathic trigeminal neuralgia（特発性三叉神経痛）, nerve block（神経ブロック）, bupivacaine hydrochloride (塩酸ブピバカイン), recurrence (再発)

緒

\section{言}

特発性三叉神経痛 (idiopathic trigeminal neuralgia ITN）はそれほど多くはないものの，高齢者を中 心にITN 患者が歯科・口腔外科を訪れることはまれ ではない. ITN の成因は未だに十分には解明されては いないが, 頭蓋内の血管による三叉神経への圧迫が, その原因の一つとして発表されてからは, ITN の発症 機序の解明が大きく前進してきた ${ }^{1,2)}$. これと共に

高知医科大学医学部歯科口腔外科学教室

(主任 : 尾崎登喜雄教授)

Department of Oral Surgery, Kochi Medical School

(Chief: Prof. Tokio Osaki)

受付日: 平成 9 年 4 月 9 日
ITN に対する治療は変遷し，近年では脳外科医による 圧迫除去手術が多くの患者に施行され，良好な治療結 果が報告されている ${ }^{3,4)}$. しかしながら，Jannetta ${ }^{2)}$ の提唱した三叉神経減圧術には, 合併症のリスクがあ ると共に, 減圧手術を行っても症状の改善の得られな いケースが報告されている5７）。らに一方では， ITN は初発時からブロック療法あるいは薬物療法が 無効な程に重症ではなく, 多くの場合, これらの療法 でコントロール可能のように思われる7 ${ }^{7,8)}$.このよう に, ITN に対する保存療法は未だ重要な位置を占めて おり, 保存的療法の検討はそれなりに意味を有するこ ととなる。

ITN の保存的治療に関して, 口腔外科の立場からの 報告は数少ない ${ }^{9,10)}$. ITN は, 軽症のものから重症の 
表 1 特発性三叉神経痛患者の年齢および性別

\begin{tabular}{crrr}
\hline 年 齢 & 男 & 女 & 計 $(\%)$ \\
\hline $40 \sim$ & 0 & 3 & $3(5.0)$ \\
$50 \sim$ & 7 & 5 & $12(20.0)$ \\
$60 \sim$ & 6 & 11 & $17(28.3)$ \\
$70 \sim$ & 4 & 13 & $17(28.3)$ \\
$80 \sim$ & 5 & 6 & $11(18.3)$ \\
\hline 計 & 22 & 38 & $60(100.0)$ \\
\hline
\end{tabular}

平均年齢 : $67.2 \pm 11.1$ 歳

ものまでさまざまであること,さらには根本的治療に 欠け, 対症療法が主であることより，再発しやすいこ となど, ITN の治療においては検討すべき点が少なく ない，そこで, ITN 治療に資するべく，当科における 今までの症例を検討し, 報告することとした，

\section{対象と方法}

対象は，1983年 1 月から 1997年 2 月までの期間に， 三叉神経支配領域に間歇性で, 持続時間の短い非症候 性の痛みを主訴に来科し，当科でITN の診断の下に 加療した60例の患者である.これらの対象患者のうち， 少数例には非ステロイド系消炎鎮痛剤が投与されてい たものの，いずれの患者においても神経痛としての治 療は当科受診までには受けておらず，当科において神 経痛に対する治療が開始された。これら60例の患者に おいて疼痛領域, 治療内容と再発, 2 次治療と再々発 等に関し, カルテの記載をもとに, 臨床的に検討した.

なお, 治療方法は, 痛みの範囲と程度, 発作の回数, 患者の年齢, 地理的条件等を総合的に考慮した上で, 個々の症例において $0.5 \%$ マーカインによる神経ブロッ クとカルバマゼピンの両者を適宜, 選択した. その基 準としては, 発作の回数が少なく, 痛みが小範囲に限 局している場合には，まずカルバマゼピンを投与し， その効果を観察する一方, 頻回に通院可能な患者では 局所麻酔剂（局麻剂）による神経ブロックを併用した. 頻回の局麻剂による神経ブロックで十分な効果が得ら れなかったもの，さらには遠隔のために頻回に通院で きず, カルバマゼピンを投与されたものの, 痛みがコ ントロールされなかったもの, および最初より広範囲 にわたる強い痛みを訴えた患者に対しては，カルバマ ゼピンを適宜投与しながら，100\%アルコールによる 支配神経ブロックを行った. 再発および再々発におい ても上記の基準に沿って加療した.

\section{結果}

対象患者は男性22例，女性38例からなり，年齢は60
表 2 三叉神経痛の罹患領域

\begin{tabular}{crrr}
\hline 罹 患枝 & 右 & 左 & 計 $(\%)$ \\
\hline II & 14 & 9 & $23(38.3)$ \\
III & 18 & 15 & $33(55.0)$ \\
I + I & 1 & 0 & $1(1.7)$ \\
II + II & 2 & 1 & $3(5.0)$ \\
\hline 計 & 35 & 25 & $60(100.0)$ \\
\hline
\end{tabular}

歳台および70歳台が17例ずつと高齢者が多く, 50歳未 満は15例であり, 平均年齢は67.2 11 .1歳であった（表 1 ).

罹患領域の中では，第四枝が最も多く33例，次いで 第 II 枝が23例であり，他に第 II 枝と第血枝の双方が罹 患したものが 3 例, 第 I 枝と第 II 枝の合併が 1 例認め られた（表 2 )。

初回治療の中では, 局麻剤による頻回（週に3〜4 回）の神経ブロックとカルバマゼピン（テグレトー ル ${ }^{\circledR}$, 日本チバガイギー) の投与が19例に行われ，カル バマゼピンの投与のみが17例, 局麻剂による神経ブロッ クのみが 9 例, さらには, アルコールによる神経ブロッ クとカルバマゼピンの併用が7例，アルコールによる 神経ブロックのみが 3 例, 神経切断/揄除術が 5 例に 施行された（表 3 ). それぞれの治療後の再発率には大 きな差がなく, 全体として25例が再発し, 再発率は 41.7\%であった。これら25例に対する治療は神経ブロッ クが主体となり, カルバマゼピンのみで治療された 4 例および捻除術が施行された 4 例を除き，他では神経 ブロックが施行された. しかしながら，これらのうち 14例は再々発を来し, 初回の再発率よりも再々発は高 率 $(56.0 \%)$ であった. なお, 再々発を来した14例のう ち 9 例 $(64.3 \%)$ においては, さらに痛みが再発した.

一次治療終了後から再発までの期間に比べ, 二次治 療終了時点から再々発までの期間はやや延長していた (表 4 ). すなわち, 前者では 25 例中 8 例は治療終了後 3 か月以内に， 8 例は 3 か月から 1 年の間に，9例は 1 年以上経てから再発した。これに対し, 再々発では 2 例が 3 か月のうちに, 3 例が 3 か月から 1 年の間に, 9 例においては 1 年以上経ってから再発した.

再発を繰り返す症例では, 痛みの範囲が広く, 発作 も頻回であった. すなわち, 初診時（初回治療時）で は, 60例中28例はオトガイ神経ないしは眼窩下神経の 領域に限局していて，第皿枝ないしは第 II枝の領域全 体の疼痛は10例にしか認められなかったのに対し，再 発時では領域全体の痛みは 25 例中 6 例とやや高率とな り，3回以上の再発例では， 7 例中 5 例に領域全体の 痛みが認められた（表 5 ). 疼痛発作の回数も, 頻回に 
表 3 初回治療と再発について

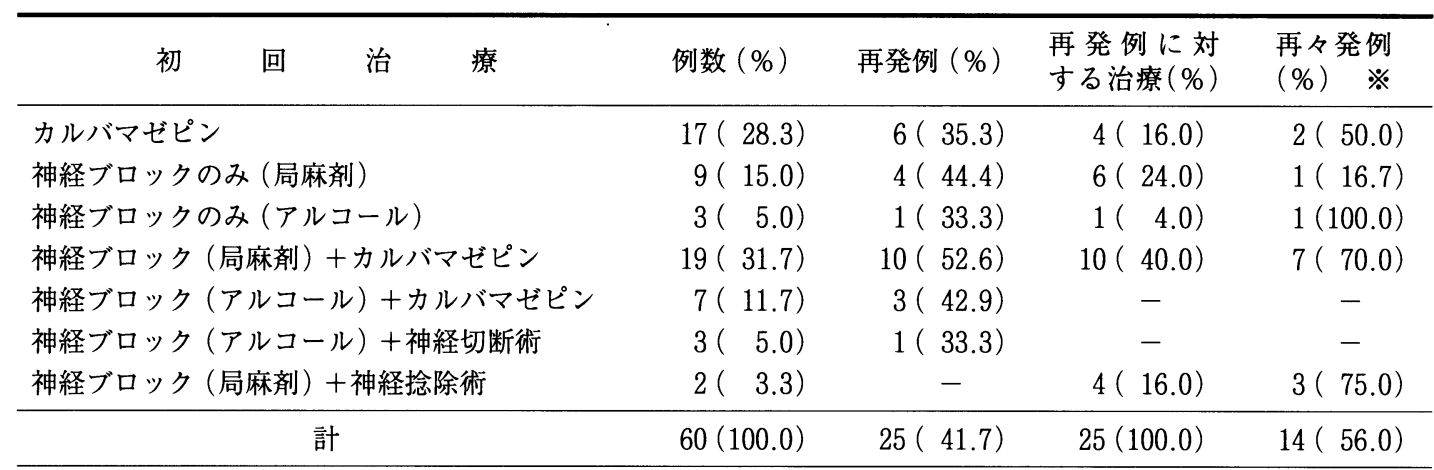

神経ブロック：オトガイ孔25例, 眼窩下孔 15 例, 下顎孔 9 例, 卵円孔 3 例, 正円孔 1 例, その他 4 例

※再発例 $(25$ 例) に対する\%

表 4 初回治療から再発および 2 次治療から再々発までの期間

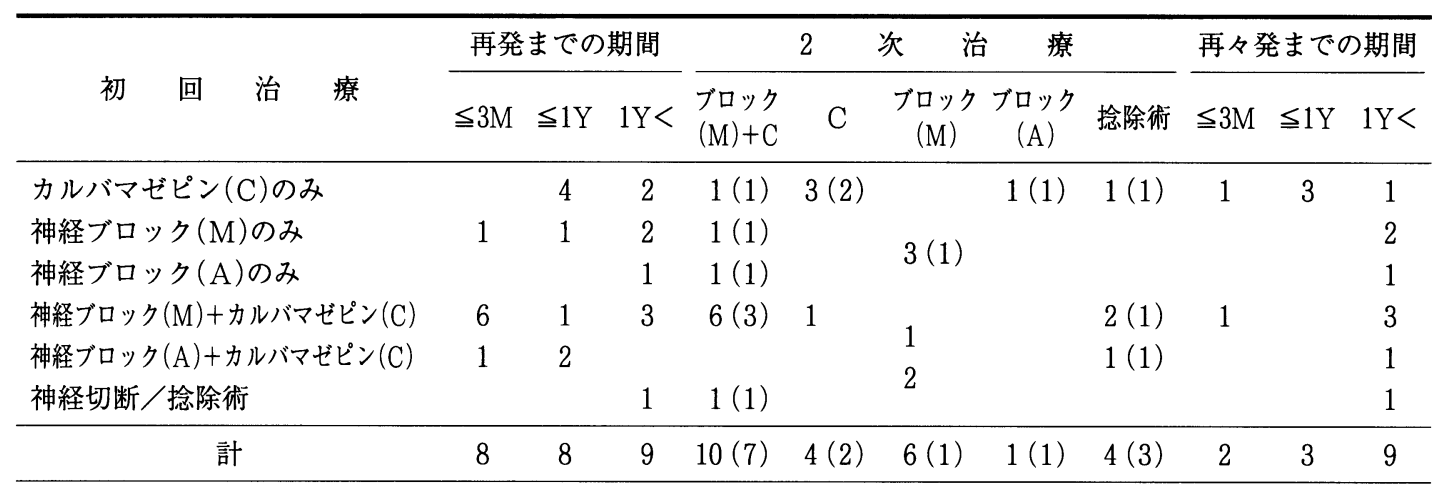

$\mathrm{M}: 0.5 \%$ マーカインによる神経ブロック土皮下留置針による持続的局麻剤の注入あるいは局麻剮軟膏の塗布

$\mathrm{A} ：$ アルコールによる神経ブロック

( ）: 再々発症例

再発した症例では多い傾向にあり, 初診時では33例が 日に数度しか発作は生じなかったのに対し，3回以上 の再発症例では, 発作の少ないものは認められなかっ た。

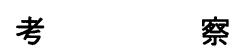

ITN は高齢者に生じる疾患であり, われわれの結果 は, 年齢, 罹患枝, 男女比, いずれについても他の報告 と同様である10 12). 高齢の患者では, 時には, 訴える 内容が整然としていないために，その内容を診断者が 十分に理解できず診断に苦慮することがある。特に， 痛みが軽症で, 誘発帯 (トリガーゾーン) が認められ なかったり，歯肉に痛みがあるものの，痛いところを 限局しがたい場合には，診断上，注意が必要である。 というのも，一方では, ITN と紛らわしい痛みが口腔,
顔面には発生するからである13,14).

治療として,われわれはほとんどの症例に対し，保 存的治療を選択しているが, ITN の原因, 痛みの誘発 メカニズムが解明されていないことはとりもなおさず, 根本的治療の不可能なことを意味し，対症的に，発作 性疼痛の治療を行うこととなる．その治療の中で, 大 きな位置を占めるのは, カルバマゼピンに代表される 薬物療法と, 局麻郕あるいはアルコールによる神経ブ ロックである.われわれは, 痛みの範囲と程度, 発作 の回数, 患者の年齢, 地理的条件等を総合的に考慮し， 神経ブロックとカルバマゼピンの両者を適宜組み合わ せ，選択している．たとえば, 軽症の場合にはまず，カ ルバマゼピンを投与し，その効果を観察することとし， オトガイ神経，あるいは眼窩下神経に限局していて， カルバマゼピンでは痛みがコントロールされない場合 には, 局麻片ないしはアルコールによる神経ブロック 
表 5 再発と痛みの関係

\begin{tabular}{|c|c|c|c|c|c|c|c|c|c|c|c|c|c|c|}
\hline \multirow{2}{*}{ 治 } & \multirow{2}{*}{ 時 } & \multirow{2}{*}{ 期 } & & \multicolumn{2}{|r|}{ 痛 } & み & の & 範 & 囲 & 発 & 作 & \multicolumn{2}{|c|}{ の 回 } & 数 \\
\hline & & & & 限 & 局 & 広 & 範 & & 領域全体 & 日に数度 & 度 & & 々 & 非常に頻回 \\
\hline \multicolumn{3}{|c|}{ 初回治療時 $(\mathrm{n}=60)$} & & & & & 22 & & 10 & 33 & & 22 & & 5 \\
\hline \multicolumn{3}{|c|}{ 再発時 $(n=25)$} & & & & & 9 & & 6 & 15 & & 9 & & 1 \\
\hline \multicolumn{3}{|c|}{ 再々発時（n=14） } & & & 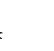 & & 6 & & 4 & 7 & & 6 & & 1 \\
\hline \multicolumn{4}{|c|}{3 回以上の再発 $(n=7) *$} & & & & 2 & & 5 & - & & 6 & & 1 \\
\hline
\end{tabular}

※再々発をきたした14例の中で, それ以降も再発を来した表中の 7 例以外に 2 例は, 当大学脳外科で開頭減圧手 術を受けている.したがって, 再々発例のうち 9 例が再発したこととなり, その率は $64.3 \%$ となる。

を施行してきた. ITN には自然緩解があり15)，それま での間の疼痛をコントロールすること, あるいは自然 完解をなるべく早く招来せしめることが保存的治療の 主なる目的であるように思われる。

神経ブロックが最もよく奏効するのは, オトガイ神 経および眼窩下神経に対してであり，本対象患者にお いても半数以上がこのいずれかの神経に対してブロッ クが行われ，下顎孔，卵円孔，正円孔に対するブロッ クはごく少数であった. 神経ブロックには, 半永久的 なブロックの目的で純アルコールあるいはフェノール が用いられる一方, 局麻剂によるブロックも施行され る.われわれは, 初回治療にあたっては作用時間が長 く, 神経線維変性作用 ${ }^{16)}$ を有する塩酸ブピバカイン (0.5\%マーカイン) を用い, 週に $3 \sim 4$ 回ブロックを 行う一方で, ITN に有効なカルバマゼピンを投与する こととしている.局麻剤による神経ブロックは，用い る局麻剂の作用時間の間だけ作用するだけでなく，頻 回にブロックを重ねると麻酔作用時間が過ぎても痛み の発作が生じなくなることもしばしば認められる16). なぜ, 頻回に局麻剤でブロックを行うと感覚の残るま まに発作が妨げるのかは，全く不明であるが，異常な 痛みの伝導を頻回にわたって遮断することが痛みの発 作を防ぐ上でよいように思われる.

ITN の保存的治療において問題となるのは再発で ある. 局麻剤によるブロック療法では, 多くは 3 か月 前後すると再発し, アルコールによるブロックよりも 効果の維持期間は短い. 再発時にも初回と同じく, 神 経ブロックと薬物療法を行い, ブロックには多くの場 合, アルコールを用いているが, アルコールによるブ ロックの恒久的な効果をもたらすのでは決してなく， やはり 3 か月から 6 か月すると再発してくるのが通例 である17).アルコールを用いても局麻剤とあまり変わ らないことからすると, アルコールよりも局麻剤を用 いるほうが得策と考えられるが, 再発例では頻回に局 麻剂でブロックしても目的を達することができない例 が多く，必然的に，アルコールを用いることとなる．

ITN は, 再発を繰り返すと, 徐々に再発までの期間
が短くなり，ブロックによる治療効果が減弱するので はないかと懸念される10). しかしながらそのような結 果は得られず,この点においては問題がないように思 われる.ただ, 問題となるのは再発するごとに発作が 頻回となり, 痛みが強まり, 有痛領域が拡大するので はないかとの危惧である. 事実, 初回治療時と再三に わたって再発した症例を比較した時, 後者では, 痛み の範囲・強さ, 発作の回数が増強されているように見 受けられた。さらに, 再発率の推移についてみると, 初回の再発率は $41.7 \%$ あるるに対し, 再々発率は $56.0 \%, 3$ 回以上の再発は $64.3 \%$ と徐々に再発率は上 昇していた.ただ,この結果は, 最初より広い範囲に わたって強い痛みを呈する場合には再発しやすいとも 理解できる. 確かに, 治療を進める経過の中で, 重症 化する症例も見受けられ, 重症の ITN は再発しやす いことと, 治療・再発を繰り返す中で重症化すること の両方の結果として本結果をとらえるべきであろう.

薬物療法とブロック療法を組み合わせても，なおか つ痛みがコントロールできない症例で，オトガイ神経 領域あるいは, 眼窩下神経領域に痛みが限局している 場合には神経捻除術，あるいは神経切断術を行ってき たが, 神経切断を行った後, 約 1 年で痛みが再発した 症例が認められた。再度，その症例に対しては外科的 に処置を行ったが，切断部に腫瘤の形成はなかったも のの, 神経線維が再生されていることが確認された。 したがって, 切断術を行う際には, 単に神経を切断す るだけではなく, $1 \mathrm{~cm}$ 位, 切除することが再発を防ぐ 上で必要であろう. なお, 再発例のうち 4 例に神経捻 除術を施行したが, そのうち 3 例は発作様疼痛が再燃 した.この結果からすると, 捻除術は確実な外科的手 段ではなく, 恒久的な除痛を得るためには神経切断術 の方がよいように思われる。

ITN に対する治療は, 種々の問題を包含しているよ うに思われる. 単に除痛を求めるだけではなく，なる ベく機能を障害することなしに，適格な除痛を得るこ とを心掛け実践することが, 困難ではあるが, 大切の ように思われる.そのためにはまず, 薬物療法と局麻 
剤による神経ブロックで治療を行うことが得策である と, 此度の結果は示しているように思われる。

\section{ま と め}

特発性三叉神経痛の患者60例（男性22例, 女性38例） を対象に, 臨床的に検討し，以下の結果を得た．1）罹 患領域は第 III枝が33例（55\%），第 II 枝が23例（38.3\%） であり，II 枝と III枝の合併が 3 例，I 枝と II 枝の合併 が1例であった．2）治療としてはほとんどの症例に， 神経ブロックとカルバマゼピン投与の少なくともいず れかが行われ，神経切断・捻除術が 5 例に行われた。 局麻剂による頻回のブロックはオトガイ神経, 眼窩下 神経に対して行われ，アルコールによるブロックと同 様な効果が得られた. 3 ) 再発は $3 \sim 6$ か月後に生じ, 1 次治療からの再発は25例 (41.7\%) に, 再々発は 25 例 中 14 例 $(56.0 \%)$ に, 3 回以上の再発は 14 例中 9 例 (61.3\%)に認められた。 4$)$ 再発症例では, 痛みは広 範囲で, 発作も頻回であった.

結果より, 局所麻酔剤による頻回の神経ブロックは, オトガイ神経および眼窩下神経領域の神経痛に対して, 長期の除痛を得る有用な手段であることが明らかとなっ た.さらに, 最初より重症なものは再発しやすいこと， 再発を繰り返すうちに重症化するものがあること等が 明らかとなり, これらの点が特発性三叉神経痛の保存 的治療における問題点と思われた。

\section{引 用 文 献}

1) Gardner, W.J.: Concerning the mechanism of trigeminal neuralgia and hemifacial spasm. J Neurosurg 19: 947-958 1962.

2) Jannetta, P.J.: Arterial compression of the trigeminal nerve at the pons in patients with trigeminal neuralgia. J Neurosurg 26: 159-162 1967.

3) Jannetta, P.J.: Microsurgical approach to the trigeminal nerve for tic douloureux. Progr Neurol Surg 7: 180-200 1976.

4）福島孝徳: 三叉神経痛一手術適応と効果・治療 66: 1779-1782 1984

5）堀 智勝, 阿武雄一: 三叉神経痛一病因論の変 遷と臨床. 医学のあゆみ 138: 618-622 1986.

6）天野恵市：頭痛の外科療法. 治療学 24: 51-54 1990.

7) Maciewicz, R., Bouckoms, A., et al.: Drug therapy of neuropathic pain. Clin J Pain 1: 39-49 1985.

8) Zakrzewska, J.M. and Patsalos, P.N.: Drugs used in the management of trigeminal neuralgia. Oral Surg Oral Med Oral Pathol 74: 439-450 1992.

9）朱雀直道, 冨岡德也, 他 : 三叉神経痛患者の臨 床統計的観察 (抄). 日口外誌 15: 2531969.

10）松田康男, 山根源之, 他: 特発性三叉神経痛の 臨床統計的観察. 日口外誌 25: 1073-1078 1979.

11）若杉文吉：三叉神経痛. 神経進歩 18: 1096-1104 1974.

12）荒木信夫, 厚東篤生: 三叉神経痛. 神経内科 29 : 126-136 1988 .

13）加藤 斎, 尾崎登喜雄, 他 : 非定型的な顔面痛 に対する臨床的検討. 日歯心身 7: 25-33 1992.

14）中川保弘, 筒井末春: 心因性頭痛. 神経内科 26 : 449-453 1987.

15）田草川 豊：三叉神経痛・舌咽神経痛をめぐる 問題点. 医学のあゆみ 177: 709-711 1966.

16）尾崎登喜雄, 渡部隆夫, 他：局所麻酔薬に関す る研究 そのIII. 局所麻酔の神経線維に対する 影響. 日歯麻誌 8: 201-207 1980.

17）柳田 尚：三叉神経痛の非観血的治療.神経進 歩 37: 867-874 1993. 